\title{
Практичне заняття
}

на передатестаційному цикмі

мікарів за фахом «Загамьна

практика-сімейна медицина»

за тематикою неврологічного огляду

хворого (АосліАження рефлексів

та чут иивості)

Свиридова Н.К.

д.мед.н., професор кафедри неврології і рефлексотерапії Національної медичної академії післядипломної освіти імені П.Л. Шупика

Довгий І.Л.

к.мед.н., доцент кафедри неврології і рефлексотерапії Національної медичної академії післядипломної освіти імені П.Л. Шупика

Середа В.Г.

к.мед.н., доцент кафедри неврології і рефлексотерапії Національної медичної академії післядипломної освіти імені П.Л. Шупика

Чередніченко Т.В.

к.мед.н., асистент кафедри неврології і рефлексотерапії Національної медичної академії післядипломної освіти імені П.Л. Шупика

Жгільова Н.O.

Аспірант кафедри неврології і рефлексотерапії Національної медичної академії післядипломної освіти імені П.Л. Шупика

\section{Резюме}

Всебічний підхід сімейного лікаря до пацієнта нерідко може стати підставою для висновків, які значно відрізняються від, отриманих при односторонньому, вузькоспеціалізованому медичному підході. Структурно-функціональну реорганізацію системи медичного обслуговування з першочерговим розвитком первинної медико-санітарної допомоги на засадах загальної практики-сімейної медицини, потрібно здійснювати підвищенням рівня кваліфікації лікарів первинної ланки 3 територіально-дільничного принципу на вільний вибір пацієнтами лікаря загальної (сімейної) практики, враховуючи медичний маршрут пацієнта. Післядипломне підвищення кваліфікації включає великий відсоток практичних занять на передатестаційному циклі лікарів за фахом «Загальна практика-сімейна медицина» за тематикою неврологічного огляду хворого (дослідження рефлексів та чутливості). Неврологічне обстеження складається з двох незалежних компонентів: збирання анамнезу захворювання та об'єктивного дослідження неврологічного статусу пацієнта. Неврологічний статус $є$ специфічним обстеженням, а більшість неврологічних розладів стосуються тільки порушень у нервовій системі, але частина з них може бути наслідком загально-соматичних порушень і тому слід провести хоча б коротке обстеження функцій серцевої, дихальної, травної та видільної систем, як і загальний огляд.

Ключові слова: неврологічний огляд, сімейний лікар, коморбідність, практичні навички, практичні заняття, післядипломна освіта

Обов'язок сімейного лікаря - надання первинної медичної допомоги будь-якому хворому, незалежно від його віку та статі. Всебічний підхід сімейного лікаря до пацієнта нерідко може стати підставою для висновків, які значно відрізняються від, отриманих при односторонньому, вузькоспеціалізованому медичному підході. Структурно-функціональну реорганізацію системи медичного обслуговування з першочерговим розвитком первинної медико-санітарної допомоги на засадах загальної практики-сімейної медицини, потрібно здійснювати підвищенням рівня кваліфікації лікарів первинної ланки з територіально-дільничного принципу на вільний вибір пацієнтами лікаря загальної (сімейної) практики, враховуючи медичний маршрут пацієнта. 
Післядипломне підвищення кваліфікації включає великий відсоток практичних занять на передатестаційному циклі лікарів за фахом «Загальна практика-сімейна медицина» за тематикою неврологічного огляду хворого (дослідження рефлексів та чутливості). Неврологічне обстеження складається з двох незалежних компонентів: збирання анамнезу захворювання та об'єктивного дослідження неврологічного статусу пацієнта.

Анамнез (або історія розвитку захворювання) $€$ в неврології надзвичайно важливим, порівняно з іншими галузями, оскільки базується на основних принципах збору анамнезу:

- дайте можливість пацієнту самостійно, своїми словами, висловити основні скарги та причину звертання до лікаря;

- постарайтесь створити атмосферу спокою, доброзичливості та довіри, щоб зняти напругу, тривогу у пацієнта, представтесь йому;

- задавайте свої уточнюючі запитання тільки після того, як висловиться пацієнт; не заперечуйте і візьміть до уваги навіть своєрідні висловлювання, які зроблені у специфічних формулюваннях, мовою, що притаманна пацієнту: Ви можете потім уточнити їх та привести до однакового розуміння того чи іншого симптому та прояву;

- будьте послідовними в опитуванні, дотримуючись наступного: наявні скарги пацієнта та причини його звертання, систематичний аналіз скарг та розвитку захворювання (таблиця 2), попередня медична історія (захворювання та втручання у минулому), життєві звички, нейровегетативні функції, особистісна та соціальна ситуація, сімейний анамнез.

Неврологічний статус є специфічним обстеженням, а більшість неврологічних розладів стосуються тільки порушень у нервовій системі, але частина з них може бути наслідком загальносоматичних порушень і тому слід провести хоча 6 коротке обстеження функцій серцевої, дихальної, травної та видільної систем, як і загальний огляд хворого (шкіра, температура, будова тіла тощо).

Дослідження неврологічного статусу може бути виконано або в послідовності обстеження окремих функцій (черепні нерви, рухова функція, чутливість, рефлекси, координація рухів), або в топографічній послідовності (голова, руки, тулуб, нижні кінцівки). Важливим принципом $€$ завершеність та повнота обстеження: у неврології неможливо обмежуватись тільки дослідженням будь-якого регіону тіла чи тільки однієї функції - зробити висновок про стан нервової системи можливо тільки тоді, коли всі функції були досліджені скрізь.

Лікар має говорити з пацієнтом, коротко пояснюючи свої дії, інструктуючи хворого. Всі знахідки мають бути відмічені та задокументовані. Окремі симптоми мають бути оцінені у кількісному вимірі (м'язова сила). Оскільки основу життедіяльності організму складають рухові реакції, які $\epsilon$ результатом скорочення скелетних м'язів, що забезпечують підтримання пози, переміщення тіла або його частин у просторі, то патологічні зміни рухів, що зустрічаються у клініці, стосуються обмежень об’єму та сили рухів, що носить назву парезу та паралічу.

Рухові реакиії поділяють на рефлекторні та довільні, або свідомі. Рефлекс - це реакція організму у відповідь на подразнення рецепторів, яка здійснюється за участю центральної нервової системи. Безумовні реббекси - це вроджені автоматичні рухові реакції, які: філогенетично давні; мають підготовлену морфологічну основу; знаходяться під регулюючим впливом кори головного мозку; є базою, на якій формуються умовнорефлекторні реакції організму.

Безумовні рефлекси замикаються на рівні спинного мозку, мозкового стовбура та підкіркових ядер. Кожен рефлекс має рефлекторну дугу (ланцюг нейронів, по якому збудження від рецепторів проходить до виконавчого органу). Функції рефлекторної дуги: здійснення рефлексу, забезпечення трофіки м'язів, підтримання тонусу м' язів. Класифікація безумовних рефбексів:

1) поверхневі або екстероцептивні:

- шкірні;

- рефлекси зі слизових оболонок.

2) глибокі або пропріоцептивні:

- сухожильні;

- періостальні;

- суглобові.

У неврологічних хворих досліджують наступні рефлекси:

1) поверхневі рефлекси зі слизових оболонок:

- рогівковий;

- кон'юнктивальний;

- глотковий;

- піднебінний.

2) шкірні рефлекси:

- черевні рефлекси;

- анальний;

- кремастерний;

- підошвовий.

3) сухожилкові рефлекси:

- згинальний ліктьовий;

- розгинальний ліктьовий;

- колінний;

- ахиллів.

4) періостальні рефлекси:

- зап’ястково-променевий;

- надбрівний рефлекс;

- нижньощелепний.

Дослідження сухожильних рефлексів

Рефлекс із сухожилка двоголового м'яза плеча (біцепс-рефлекс).

Викликається ударом неврологічного молоточка по сухожилку двоголового м'яза плеча в ліктьовому згині. При цьому передпліччя досліджуваного підтримується лівою рукою досліджуючого. Відповідь полягає в скороченні м'язів і згинанні в ліктьовому суглобі. Рефлекторна дуга: м'язово-шкірний нерв, V i VI шийні сегменти спинного мозку.

Рефлекс із сухожилка триголового м'яза плеча (трииепс-рефлекс).

Викликається ударом молоточка по сухожилку триголового м'яза плеча на 1-1,5 см вище лік- 
тьового відростка ліктьової кістки (olecranon). Обстежуючий підтримує зігнуту руку пацієнта за ліктьову ділянку (мал. 2a), або рука досліджуваного повинна бути зігнутою під прямим кутом і підтримуватися лівою рукою обстежуючого. Викликаною реакцією є скорочення м'яза й розгинання руки в ліктьовому суглобі. Рефлекторна дуга: променевий нерв, VII-VIII сегменти шийного відділу спинного мозку.

\section{Колінний рефлекс}

Викликається при ударі молоточком по сухожилку чотириголового м'язу стегна нижче колінної чашечки. Досліджуваний сидить на стільці, поставивши ноги так, щоб гомілки знаходилися під тупим кутом до стегон, а підошви торкалися до підлоги або досліджуваний, сидячи на стільці, закидає ногу на ногу (мал.3). Рефлекс полягає в скороченні чотириголового м'яза стегна і розгинанні ноги в колінному суглобі. Рефлекторна дуга: стегновий нерв, II та IV поперекові сегменти спинного мозку.

\section{Рефлекс з ахіллового сухожилка}

Викликається ударом молоточка по ахілловому сухожилку. Дослідження можна проводити, поставивши досліджуваного на коліна на кушетку чи на стілець, щоб стопи вільно звисали, а руки впиралися в стіну або в спинку стільця. Можна обстежувати, коли досліджуваний лежить на животі. У такому випадку досліджуючий, захвативши лівою рукою пальці обох стоп досліджуваного й зігнувши його ноги під прямим кутом у гомілковостопних та колінних суглобах, правою рукою наносить молоточком удари. Реакція полягає в підошовному згинанні стопи. Рефлекторна дуга: великогомілковий нерв, I і II крижові сегменти спинного мозку.

Дослідження шкірних рефлексів включає поверхневі черевні рефлекси - швидке проведення штриху молоточком по шкірі живота в напрямку ззовні до середньої лінії (нижче реберних дуг верхній, на рівні пупка - середній і над пахвинною складкою - нижній черевні рефлекси) викликає скорочення м'язів черевної стінки. Рефлекторні дуги: міжреберні нерви, грудні сегменти спинного мозку (VI-VIII для верхнього, IX-X для середнього, XI-XII для нижнього черевних рефлексів).

Підошовний рефлекс викликається нанесенням штриху молоточком по шкірі зовнішнього краю підошви, внаслідок чого виникає згинання пальців стопи. Підошовний рефлекс викликається краще, коли досліджуваний лежить на спині і його ноги дещо зігнуті. Можна проводити дослідження, поставивши досліджуваного на коліна на кушетку чи стілець.

Рефлекторна дуга: сідничний нерв, V поперековий - II крижовий сегменти спинного мозку.

\section{Дослідження періостальних рефлексів}

\section{П'ясно-променевий реблекс}

Викликається ударом молоточка по шилоподібному відростку променевої кістки (мал.5а). Реакція у відповідь - згинання руки в ліктьовому суглобі, пронація кисті, згинання пальців. При дослідженні рефлексу рука повинна бути зігнута під прямим кутом у ліктьовому суглобі, кисть дещо пронована. При цьому кисті можуть лежати на стегнах досліджуваного в положенні сидячи або утримуватися лівою рукою досліджуючого (мал.5б). Рефлекторна дуга: нерви - серединний, променевий, м'язово-шкірний; V-VIII шийні сегменти спинного мозку, які іннервують м'язи пронатори, плечопроменевий м’яз, згиначі пальців, двоголовий м'яз плеча.

Забезпечення довільних рухів. Довільні рухи це свідомі рухові реакції, для здійснення яких обов'язкова участь кори головного мозку. Рухові центри кори головного мозку розташовані переважно попереду центральної борозни, тобто в лобовій частці мозку:

- в передцентральній звивині;

- в парацентральній часточці;

- в прилеглих ділянках лобової частки.

У передніх відділах лобової частки (префронтальна ділянка) відбувається інтеграція всіх інформаційних сигналів та формується модель рухового акту.

Відростки рухових нейронів кори головного мозку зв'язують рухові центри з клітинами передніх рогів спинного мозку, рухових ядер черепних нервів та клітинами підкіркових базальних ядер, утворюючи рухові низхідні шляхи. Ці рухові шляхи поділяють на 3 системи: пірамідні шляхи, екстрапірамідні шляхи та мозочкові шляхи.

Аксони клітин Беца утворюють рухові пірамідні шляхи, які є складовою кірково-м'язових шляхів (назва не анатомічна, введена клініцистами). По кірково-м'язовому шляху рухові імпульси прямують до м’язів, забезпечуючи їх іннервацію та скорочення.

\section{Будова та хід кірково-м'язового шляху}

Цей шлях двохнейронний, утворений центральними та периферичними мотонейронами.

Центральні мотонейрони - це тіла пірамідних клітин Беца з їх аксонами. Аксони центральних нейронів утворюють пірамідний шлях, що складається $з$ двох пучків - кірково-ядерного та кірково-спинномозкового.

Периферичні нейрони - тіла та аксони рухових клітин передніх рогів спинного мозку, рухові ядра, корінці та волокна черепних нервів.

Завдяки неповному перехресту пірамідного шляху забезпечується двобічна кіркова іннервація м'язів. Проте, не у всіх групах м'язів вона $є$ однаковою. Найбільше виражена у м'язах, що іннервуються черепними нервами, м'язах шиї, тулуба, промежини. Найменше вона представлена у м'язах язика та кінцівок, мімічних м'язах нижньої частини обличчя. Тому саме ці м'язи частіше не отримують іннервацію у разі ураження нервової системи.

Таким чином, центральні нейрони рухового шляху здійснюють зв'язок рухової ділянки кори з сегментарним апаратом спинного мозку та мозкового стовбура. Весь комплекс клітин, за допомогою яких здійснюється цей зв'язок, має назву «пірамідна система». 


\section{Функиії пірамідної системи:}

1) приймає участь у виконанні довільних рухів, надсилаючи імпульси до стовбурових та спінальних сегментарних апаратів;

2) регулює функції сегментарних апаратів активує альфа-великі мотонейрони передніх рогів спинного мозку та гальмує діяльність рефлекторних дуг;

3) обмежує поширення імпульсів збудження по нейронах спинного мозку;

4) гальмує рефлекторні автоматизми підкіркового, стовбурового та спінального рівнів.

\section{Ознаки ураження кірково-м'язового шляху}

Якщо кірково-м'язовий шлях уражується на будь-якому рівні, відповідні м’язи не отримують іннервації від кори, довільні рухи у м'язах стають неможливими, м'яз перестає скорочуватись, виникає його параліч (плегія).

У разі часткового пошкодження рухового шляху є неповна втрата довільних рухів, обмеження об'єму руху м'язів, обумовлене порушенням їх іннервації. Це носить назву парезу м'язів, який розрізняється:

1) параліч (парез) однієї кінцівки - моноплегія (монопарез, плегія руки, ноги);

2) параліч обох кінцівок з одного боку - геміплегія (геміпарез);

3) параліч симетричних кінцівок - верхня або нижня параплегія (парапарез);

4) параліч верхніх та нижніх кінцівок - тетраплегія (тетрапарез).

Якщо вражається центральний нейрон рухового шляху, виникає центральний параліч. У разі пошкодження периферичного нейрону - виникає периферичний параліч. Таким чином, назва паралічу походить від назви ураженого нейрона.

Особливості центрального паралічу (парезу):

$\checkmark$ ураження центральних нейронів охоплює цілі пучки волокон пірамідного шляху, тому виникає центральний параліч не окремих м'язів, а цілих їх груп;

$\checkmark$ центральний параліч (парез) носить назву спастичного, тому що супроводжується підвищенням м'язового тонусу;

$\checkmark$ у разі пошкодження центральних нейронів знімається контроль пірамідної системи за тонічною діяльністю сегментарного апарату, за діяльністю спінальних рефлекторних дуг - підвищується м'язовий тонус переважно в екстензорах ноги та флексорах руки;

$\checkmark$ підвищуються сухожилкові та періостальні рефлекси (гіперрефлексія), оскільки розгальмовується діяльність рефлекторних дуг на рівні сегментарного апарату;

$\checkmark$ при розвитку сухожилкової гіперрефлексії з'являються клонуси стоп, кисті та пригнічуються шкірні черевні, підошовні рефлекси, виникнення яких пов'язане з формуванням пірамідних шляхів (з'являються патологічні рефлекси);

$\checkmark$ центральний параліч м'язів нерідко супроводять розлади сечовипускання та дефекації. Центри цих функцій знаходяться в сірій речовині спинного мозку на рівні бічних рогів S2 - S4 сегментів. Свідомий контроль за сечовипусканням забезпечується завдяки зв'язкам цих центрів з корою півкуль головного мозку через волокна пірамідних шляхів. Їх двобічне ураження супроводжується розладами тазових функцій. Виникає періодичне нетримання сечі (періодичне рефлекторне спорожнення сечового міхура без свідомого контролю у разі розтягнення його сечею), інколи затримка сечі, імперативні поклики до сечовипускання.

Центральний параліч виникає у разі ураження передцентральної звивини, променистого вінця, внутрішньої капсули, стовбура мозку та спинного мозку.

Особливості периферичного паралічу (парезу):

$\checkmark$ ураження периферичного нейрону в будьякій його ділянці призводить не тільки до перериву рухового кірково-м'язового шляху, але й веде до розриву сегментарної рефлекторної дуги в iï еферентній ланці (стають неможливими як довільні, так і рефлекторні рухи, виникає арефлексія або гіпорефлексія рефлексів, що замикаються на рівні ураження);

$\checkmark$ спостерігається м'язова атонія або гіпотонія, оскільки внаслідок розриву спінальної рефлекторної дуги м'язові волокна не отримують тонічних імпульсів, тому периферичний параліч називають в'ялим;

$\checkmark$ через 2-3 тижні після початку пошкодження периферичних нейронів у відповідних м'язах спостерігається атрофія, бо до м'язів в результаті розриву рефлекторної дуги, не надходять трофічні впливи;

$\checkmark$ три характерні ознаки периферичного паралічу: арефлексія; атонія м'язів; атрофія м'язів;

$\checkmark$ у разі хронічних прогресуючих процесів у передніх рогах спинного мозку або в рухових ядрах черепних нервів (частіше за наявності бічного аміотрофічного склерозу) виникає подразнення тіл периферичних мотонейронів і у м'язах з'являються фібрилярні посмикування;

$\checkmark$ периферичний параліч характеризується виникненням реакції переродження або дегенерації, яка проявляється змінами реакцій на електричний струм уражених нервів та м’язів, що ними іннервуються.

Зазвичай периферичні паралічі виникають за наявності ураження:

- передніх рогів спинного мозку;

- рухових ядер черепних нервів та їх корінців;

- передніх корінців спинного мозку;

- шийного, плечового, поперекового та крижового сплетень;

- периферичних нервів.

\section{Дослідження чутливості при неврологічному} обстеженні

Чутливість - це здатність організму сприймати подразнення зовнішнього та внутрішнього середовища. Рецепція - це сукупність всіх аферентних систем, які сприймають подразнення зовнішнього і внутрішнього середовища і проводять їх до центру. Рецепція - це більш широке 
поняття ніж чутливість, так як ми не все відчува$€ м о$, що сприймаємо. Чутливість - це та частина рецепції, яку ми відчуваємо, аналізуємо відповідними ділянками головного мозку, тобто, що чутливість тісно пов'язана з діяльністю аналізаторів.

Аналізатор - це єдина функціональна система, що складається з наступних елементів:

1) сприймаючого апарату (рецепторів) - рецепторний відділ;

2) чутливих провідників - провідниковий відділ;

3) коркового відділу, що сприймає інформацію, аналізує та синтезує іiі.

Основні завдання аналізатора - це сприймати та аналізувати подразнення. Виділяють аналізатори для різних видів чутливості (поверхневої та глибокої):

а) зоровий;

б) слуховий;

в) нюховий;

г) смаковий.

Peцептори - це чутливі утвори, які мають здатність сприймати ті чи інші зміни зовнішнього та внутрішнього середовища і передавати їх у вигляді імпульсу.

Рецептори поділяються на:

1) екстерорецептори (знаходяться в шкірі та зовнішніх слизових оболонках);

2) пропріорецептори (знаходяться в м'язах, сухожилках, суглобах);

3) інтерорецептори (знаходяться в внутрішніх органах, в судинах).

Екстерорецептори сприймають поверхневу чутливість (тактильну, больову, температурну) і діляться на механорецептори (дотик, тиск), терморецептори (тепло, холод), ноціцептори (сприймають біль).

На холодові подразники реагує більша частина волокон, ніж на теплові, біль сприймається вільними нервовими закінченнями, що розміщені між епідермальними клітинами.

Пропріорецептори знаходяться в глибоких тканинах (м'язах, суглобах, сухожилках). М'язові рецептори різноманітні, але найбільш інформативними у діагностиці $є$ нервово-м'язові веретена, які реагують на розтягнення м'язів (покриті футляром сполучної тканини і знаходяться між волокнами поперечносмугастих м'язів інтра- i екстрафузально). Крім того ще існують осморецептори, хеморецептори, барорецептори та інші. Від рецепторного апарату імпульси надходять по нервових волокнах, які є аксонами псевдоуніполярних клітин спинномозкового ганглія.

\section{Існує 3 типи волокон:}

1) Тип А - тонкі мієлінові волокна, що проводять глибоку і тактильну чутливість, швидкість проведення імпульсів по цих волокнах 40-60 м/с.

2) Тип В - мієлінові волокна, що проводять больову і температурну чутливість зі швидкістю $10-15 \mathrm{~m} / \mathrm{c}$.

3) Тип C - безмієлінові волокна, що проводять дифузну нелокалізовану больову чутливість зі швидкістю 1-1,5 м/с.

\section{Класифікація видів чутливості}

I. В основу покладено місие виникнення подразнення:

1) екстероцептивна;

2) інтероцептивна;

3) пропріоцептивна.

II. В основу покладено біологічний приници виникнення чутливості:

1) ротопатична (вітальна, ноціцептивна, таламічна) чутливість;

2) епікритична чутливість.

В клінічній практиці використовують класифікацію, в основі якої лежить розпізнавання виду подразнення, згідно якого чутливість поділяють:

1) поверхнева;

2) глибока;

3) складна.

1) До поверхневої чутливості відноситься:

а) тактильна чутливість - відчуття дотику, яке досліджується дотиком ватки, кінчика молоточка;

b) больова чутливість - відчуття болю, що досліджується голочкою (гостро чи тупо);

c) температурна чутливість - відчуття холоду чи тепла, яке досліджується за допомогою двох пробірок (з холодною та гарячою водою);

d) відчуття тріхоестезії - відчуття дотику до волосся;

е) гігрестезія - відчуття вологості;

f) відчуття лоскоту.

2) До глибоких видів чутливості відноситься:

a) м'язово-суглобова чутливість;

b) вібраційна чутливість;

c) чутливість маси;

d) чутливість тиску;

е) кінестетична чутливість.

М'язово-суглобове чуття - це відчуття, в основі якого лежить розпізнавання пасивних рухів в суглобах. Дослідження цього чуття завжди починаємо з рухів в суглобах пальців, потім -

в променево-зап'ястному суглобі, далі - в ліктьовому. Втрата м'язово-суглобового чуття викликає розлади рухів (сенситивна атаксія).

Статична атаксія в ногах досліджується за допомогою проби Ромберга - коли хворого просять стояти 3 витягнутими вперед руками і поставленими разом ступнями. При атаксії виявляється похитування і нестійкість, які підсилюються при закриванні очей.

Статичну атаксію в руках досліджуємо наступним чином: просимо хворого протягнути вперед руки і розставити пальці. При наявності атаксії в пальцях рук мимовільно з'являються спонтанні рухи (псевдоатетоз).

Динамічна атаксія в руках досліджується за допомогою пальце-носової проби, а динамічна атаксія в ногах досліджується за допомогою п'ятково-колінної проби.

Вібраційне чуття - досліджується вібруючим камертоном, коли ніжка камертона ставиться на кістковий виступ (напр., тил кисті, ступні) i визначається кількість секунд, протягом яких хворий відчуває вібрацію камертона. В нормі ві- 
браційне чуття в руках складає - 15-20 секунд, в ногах - 10-15 секунд.

Відчуття маси (ваги) досліджується з допомогою гирьок, які кладуть хворому на витягнуту руку. В нормі хворий повинен розпізнати різницю ваги в 15-20 грамів.

Відуття тиску визначається легким натисненням пальця або пристроєм барестезіометром. Хворий повинен відчувати тиснення різної сили відрізняти тиск від дотику.

Кінестетичне чуття визначається відчуттям руху шкірної складки.

3) До складних видів чутливості відноситься:

a) стереогностичне чуття;

b) двомірно-просторове чуття;

c) відчуття локалізації;

d) відчуття дискримінації.

Стереогностичне чуття - (трьохмірнопросторове чуття) - відчуття та розпізнавання предмету на дотик з закритими очима. Це складний вид чутливості, в основі якого лежить сприйняття окремих властивостей предмету (вага, форма, поверхня, розміри) при ураженні тім'яної долі кори головного мозку.

Двомірно-просторове чуття - це відчуття та розпізнавання з закритими очима написаних на шкірі букв, цифр, фігур.

Відчутmя локалізації - це здатність хворого вказати точне місце нанесеного подразнення.

Відчуття дискримінації - це здатність хворого розпізнавати два одночасно нанесених однакових подразнення.

Методи дослідження чутливої сфери (види й типи чутливих розладів)

В залежності від якісних та кількісних змін відитmiв розрізняють наступні види чутливих розладів:

1) анестезія - повна втрата чутливості;

2) гіпестезія - зниження чутливості;

3) гіперестезія - підвищення чутливості внаслідок зниження порогу збудливості в корі головного мозку;

4) дизестезія - спотворення чутливості, коли замість одного подразнення хворий відчуває зовсім інше;

5) гіперпатія - виникає внаслідок підвищення порога збудливості, коли з'являються сильні, неприємні, погано локалізовані відчуття після нанесеного подразнення;

6) синестезія - відчуття подразнення не лише в місці його нанесення, але і в іншому місці;

7) поліестезія - відчуття одного подразнення, сприймається як подразнення багатьох нанесених подразнень;

8) аллохейрія - відчуття подразнення в симетричній ділянці на протилежній частині тіла;

9) аллоестезія - відчуття подразнення в іншому місці.

Суб'єктивні види чутливих розладів:

1) парестезії - це відчуття повзання мурашок, холоду, печії, жару, затерпання, свербіж, поколювання (парестезії $€$ першими ознаками ураження нервової системи);
2) больові відчуття можуть виникати при ураженні чутливих аналізаторів на будь-якому рівні (від рецепторів до кори головного мозку).

В залежності від якісних та кількісних змін відчуттів розрізняють наступні види болю:

а) місцевий біль - це біль, що співпадає з місцем ураження;

b) проекційний біль - це біль не тільки в місці подразнення, але і дистальніше по ходу нервів чи корінців (наприклад, фантомні болі);

c) іррадіюючий біль - це біль, що розповсюджуються з одної гілки нерва на іншу не уражену (наприклад, при невралгії I гілки трійчастого нерва болі розповсюджуються в зону іннервації II чи III гілки, в верхню чи нижню щелепи);

d) відображений біль - це біль в зонах Захар'їнаГеда при захворюваннях внутрішніх органів, коли виникає іррадіація подразнення в відповідну зону на шкірі через клітини задніх рогів (напр., болі по ульнарному краю лівого передпліччя і кисті при розвитку стенокардіiі);

е) каузальгії - інтенсивний пекучий біль, який виникає без подразнення;

f) реактивний біль - це біль, що виникає при пальпації больових точок.

В залежності від якісних та кількісних змін відуттів розрізняють наступні розрізняють наступні типи чутливих порушень:

1) периферійний тип;

2) сегментарний тип;

3) провідниковий тип.

Периферійний тип виникає при ураженні дендритів I нейрону всіх видів чутливості та поділяється на:

а) мононевритичний підтип (або невральний) виникає при ураженні одного периферійного нерва $з$ порушенням всіх видів чутливості в зоні іннервації нерва, біль в ділянці нерва, гіперпатія, гіпералгезія, каузалгія, біль при пальпації);

b) поліневритичний підтип - виникає при множинному, симетричному ураженні периферійних нервів (проявляється чутливими порушеннями в дистальних відділах кінцівок у вигляді «шкарпеток» та «рукавичок»);

c) плексалгічний підтип - виникає при ураженні сплетення, проявляється порушенням чутливості в зоні іннервації сплетення, супроводжується болем, руховими розладами (парез групи м'язів, що іннервуює сплетення).

Сегментарний тип чутливих розладів буває при ураженні чутливих волокон на рівні сегмента спинного мозку (напр., при ураженні міжхребцевого ганглія, задніх корінців, задніх рогів, передньої білої спайки):

а) сегментарно-корінцевий підтип виникає при ураженні заднього корінця або при одночасному ураженні корінця і міжхребцевого чутливого ганглія.

При ураженні заднього корінця виникає втрата всіх видів чутливості в зоні іннервації корінця по 
сегментарному типу. Чутливі розлади проявляються у вигляді поперечних смуг на тулубі. Цей тип чутливих порушень виникає при радикулітах, екстрамедулярних пухлинах, коли першим при розростанні пухлини реагує задній корінець.

b) сегментарно-дисоиійований підтип виникає при ураженні задніх рогів спинного мозку та передньої сірої спайки.

В цьому випадку чутливі розлади проявляються у вигляді втрати або зниження больової та температурної чутливості при збереженні тактильного та м'язово-суглобового чуття в даному сегменті. Такі розлади називаються дисоційованими і виникають в результаті того, що в задніх рогах і передній сірій спайці проходять провідники поверхневих видів чутливості. При ураженні задніх корінців чи заднього рогу природно знижуються або згасають рефлекси, в рефлекторне кільце яких входить даний задній корінець чи задній ріг.

Провідниковий тип виникає при ураженні чутливих провідників.

Синдроми ураження чутливих шляхів на різних рівнях.

1) ураження периферійного нерва - проявляється випадінням всіх видів чутливості в ділянці нерва, болями, парестезіями;

2) ураження заднього корінця - проявляються втратою всіх видів чутливості по сегментарному типу в зоні іннервації даного сегменту;

3) ураження заднього рогу спинного мозку викликає такі ж ураження, як і при ураженні заднього корінця, тільки спостерігаються дисоційовані розлади чутливості;

4) ураження передньої сірої спайки викликає сегментарно-дисоційовані розлади чутливості двохсторонні, симетричні;

5) ураження заднього стовпа спинного мозку викликає порушення глибокого чуття на своїй стороні по провідниковому типу;

6) ураження бокового стовпа спинного мозку викликає порушення больового і температурного чуття на протилежній стороні по провідниковому типу;

7) ураження всього поперечника спинного мозку анестезія всіх видів чутливості нижче рівня ураження (глибоких з рівня ураження, поверхневих - на 2-3 сегменти нижче) - центральний параліч, тазові, трофічні розлади;

8) ураження медіальної петлі - викликає такі порушення, як геміанестезія геміатаксія;

9) ураження зорового горба - викликає такі порушення, як геміанестезія, геміатаксія, геміанопсія, геміалгія;

10) ураження чутливих иляхів у внутрішній капсулі - викликає такі порушення, як геміанестезія, гемі атаксія (не проявляється із-за парезу), геміанопсія, геміплегія;

11) ураження задньої иентральної звивини викликає такі порушення, як моноанестезія на протилежній стороні;

12) подразнення задньої иентральної звивини викликає такі порушення, як сенсорний «Джексон».
Дослідження координації рухів. Порушення координації рухів визначають терміном «атаксія»неузгодженість роботи різних м'язових груп, яке призводить до порушення точності, пропорційності, ритмічності, швидкості довільних рухів, порушення здатності підтримувати рівновагу. Порушення координації рухів можуть виникати внаслідок ураження мозочка.

Мозочкова атаксія - півкулі мозочка головного мозку контролюють іпсилатеральні кінцівки і несуть відповідальність за координацію, плавність і точність рухів:

а) статико-локомоторна атаксія виявляється при стоянні, ході, рухах тулуба і проксимальних відділів кінцівок (характерна для ураження черв'яка мозочка).

b) динамічна атаксія виявляється при довільних рухах кінцівок, переважно в їх дистальних відділах (характерна для ураження півкуль мозочка) і проявляється на стороні ураження.

\section{Клінічні прояви включають:}

а) термінальну (помітну в кінці руху) дисметрію (невідповідність тій мірі скорочення м'язів, яка потрібна для точного виконання руху);

b) інтенційний тремор (тремтіння, що виникає в рухомій кінцівці при наближенні їі до предмету або точному виконанні діі);

c) адіадохокінез (порушення здатності швидко змінювати протилежні рухи);

d) асінергї (порушення координації роботи декількох м’язових груп, що призводить до нечіткості виконання складних рухів і вимагає одночасного скорочення ряду м’язів).

Для виявлення мозочкової атаксії використовують тести.

1) Пальие-носова проба - виконується в положенні хворого сидячи спочатку з відкритими очима, потім - з закритими очима.

Лікар просить пацієнта відвести убік випрямлену руку і потім швидко наблизити вказівний палець до кінчика власного носа. Пропонує повторити ту ж пробу іншою рукою. У нормі рухи швидкі, плавні і точні.

\section{2) П’ятково - колінна проба.}

Лікар просить пацієнта, який лежить на спині, високо підняти одну ногу, потім торкнутися п’ятою цієї ноги до коліна іншої ноги, після чого повільно, ледь торкаючись до поверхні шкіри, провести п’ятою вниз по передній поверхні гомілки з відкритими, а потім із закритими очима.

\section{3) Проби на адіадохокінез.}

Лікар роз'яснює завдання для хворого на синхронне виконання двома руками швидких альтернативних рухів:

- просять хворого зігнути руки в ліктьових суглобах, розвести і злегка зігнути пальці і в такому положенні швидко міняти пронацію на супінацію кисті (імітувати викручування електричної лампочки), по черзі однією і іншою рукою, потім обома руками синхронно; 
- просять хворого швидко ударяти по своєму правому стегну по черзі долонею і тилом правої кисті; потім те ж виконати лівою рукою, а потім обома руками одночасно.

Нездатність виконати швидкі альтернативні завдання в будь-якому з цих тестів позначається терміном адіадохокінез. При ураженні пірамідної системи такі точні довільні рухи виконуються уповільнено, та при ураженні мозочка порушуються чіткість, темп, ритмічність і амплітуда цих рухів.

4) Проба на виявлення симптому «віддачі» (симптом рикошету, феномен зворотнього поштовху).

Лікар просить пацієнта зігнути руку в ліктьовому суглобі і з силою утримувати її в такому положенні всупереч опору, яке йому надають, намагаючись розігнути руку. Раптово відпускають руку, переставши протидіяти хворому. При симптомі «віддачі» рука пацієнта з силою вдаряє хворому в груди, оскільки порушується баланс між роботою м'язів згиначів і розгиначів передпліччя (асинергія), а іннервація м'язів-антагоністів, що початково напружувала м'язи (розгиначі) не встигає вчасно включитися. У здорових пацієнтів симптому «віддачі» не виникає, оскільки при усуненні опору в роботу миттєво включаються розгиначі, що запобігають зворотньому удару.

5) Проба Бабінського.

Лікар просить пацієнта, який лежить на жорсткому ліжку на спині зі схрещеними на грудях руками сісти без допомоги рук. При наявності мозочкової асинергії при такій спробі у хворого піднімаються вгору нижні кінцівки, а не тулуб; при односторонньому ураженні мозочка відповідна нога піднімається вище. Цей феномен пояснюють асинергією м'язів тулуба: при спробі сісти не відбувається одночасного скорочення сідничних м'язів, які в нормі при сіданні сприяють утриманню ніг на поверхні ліжка.

6) Проба з установкою рук на заданому рівні

Лікар просить пацієнта встановити витягнуті вперед руки на певному заданому рівні, потім опустити (або підняти) руки, закрити очі, після чого швидко підняти (або опустити) руки до заданого рівня. При мозочковій недостатності рука на стороні ураження здійснює надлишкове переміщення (дисметрія).

7) Скандована мова.

Асинергія мовної мускулатури призводить до порушення модуляції голосу, уповільнення мови. Кожен звук вимовляється з різною силою і швидкістю, що порушує плавність мови, робить iï «поштовхоподібною». Лікар просить пацієнта вимовити речення, а також кілька коротких фраз; оцінюємо плавність мови.

Сенситивна атаксія Для виявлення сенситивної атаксії використовують проби на дисметрію (пальце-носову і п’ятково-колінну, проби на обведення пальцем намальованого кола, «малювання» в повітрі вісімки); на адіадохокінез (пронація і супінація кисті, згинання та розгинання пальців). Перевіряють функцію стояння і ходи з за- критими і відкритими очима. Сенситивна атаксія зменшується при включенні зорового контролю і збільшується при закриванні очей. Інтенційний тремор для сенситивної атаксії не характерний. Розвивається при порушенні функції шляхів глибокої м'язово-суглобової чутливості, частіше при патології задніх канатиків спинного мозку, рідше - при ураженнях периферичних нервів, задніх спинномозкових корінців, медіальної петлі в стовбурі мозку або таламуса. Відсутність інформації про положення тіла в просторі викликає порушення зворотної аферентації і атаксії.

\section{Висновки}

Науково обгрунтований прогноз потреби у медичних кадрах різних спеціальностей з урахуванням напрямків і темпів структурних і функціональних перетворень в системі охорони здоров'я України, зокрема розвитку загальної практикисімейної медицини, потребує забезпечення якісної підготовки спеціалістів для первинної ланки охорони здоров'я: лікарів загальної (сімейної) практики. Розширення тематики практичних занять на передатестаційному циклі лікарів за фахом «Загальна практика-сімейна медицина» за тематикою неврологічного огляду хворого (дослідження рефлексів та чутливості) сприяє покращенню післядипломної підготовки лікарів цього фаху.

\section{Література}

1. Неврологія, за ред. С.М.Віничука. - К.: Здоров'я, 2008. - 664 с.

2. Биллер Х. Практическая неврология, пер. с англ., т. 2: Лечение. - М.: Медицинская литература. - 2005. - 416 с.

3. Болезни нервной системы, под ред. Н.Н. Яхно, Д.Р. Штульмана, изд. второе, М.: Медицина. 2001. - т. 1. - 744c., т. 2. -480 с.

4. Карлов В.А. Терапия нервных болезней - М.: Медицина. - 1996. - 653 с.

5. Никифоров А.С., Коновалов А.Н., Гусев Е.И. Клиническая неврология -М.:Медицина. 2002. - т. 1 - 690 с., т. 2 - 777 с.

6. Неврология, под ред. Д.Р.Штульмана, О.С. Левина, 4-е изд. - М.: Медпрессинформ. - 2005. - 944 с.

7. Скоромец А.А. Нервные болезни: учебн. пособие / А.А.Скоромец, А.П.Скоромец, Т.А.Скоромец. - 4-е узд. - М.: МЕДпрессинформ, 2010. - 560 с.

8. Шевага В.М. Неврологія: підручник / В.М.Шевага, А.В.Паєнок, Б.В.Задорожна. 2-е вид., перероб. I доп. - К.: Медицина, 2009. - 656 c.

9. Штульман Д.Р. Неврология: Справочник практ. врачей (Д.Р.Штульман, О.С.Левин. 6-е изд., доп. и перераб. - М.: Медпрессинформ., 2008. - 1024 с. 
Практическое занятие на предаттестационном цикле врачей по специальности «Общая практикасемейная медицина" по тематике неврологического осмотра больного (исследование рефлексов и чувствительности)

\section{Свиридова Н.К.}

д.мед.н., профессор кафедры неврологии и рефлексотерапии Национальной медицинской академии последипломного образования имени П.Л. Шупика

\section{Довгий И.Л.}

к.мед.н., доцент кафедры неврологии и рефлексотерапии Национальной медицинской академии последипломного образования имени П.Л. Шупика

\section{Середа В.Г.}

к.мед.н., доцент кафедры неврологии и рефлексотерапии Национальной медицинской академии последипломного образования имени П.Л. Шупика

Чередниченко Т.В.

к.мед.н., ассистент кафедры неврологии и рефлексотерапии Национальной медицинской академии последипломного образования имени П.Л. Шупика

Жгилева Н.А.

Аспирант кафедры неврологии и рефлексотерапии Национальной медицинской академии последипломного образования имени П.Л. Шупика

\section{Резюме}

Всесторонний подход семейного врача к пациенту нередко может стать основанием для выводов, которые значительно отличаются от полученных при одностороннем, узкоспециализированном медицинском подходе. Структурно-функциональную реорганизацию системы медицинского обслуживания с первоочередным развитием первичной медикосанитарной помощи на принципах общей практики семейной медицины, нужно осуществлять повышением уровня квалификации врачей первичного звена с территориально-участковому принципу на свободном выборе пациентами врача общей (семейной) практики, учитывая медицинский маршрут пациента. Неврологическое обследование состоит из двух независимых компонентов: сбор анамнеза заболевания и объективного исследования неврологического статуса пациента. Неврологический статус является специфическим обследованием, а большинство неврологических расстройств касаются только нарушений в нервной системе, но часть из них может быть следствием общесоматических нарушений и поэтому следует провести хотя бы короткое обследование функций сердечной, дыхательной, пищеварительной и выделительной систем, как и общий обзор .

Ключевые слова: неврологический осмотр, семейный врач, коморбидность, практические навыки, практические занятия, последипломное образование

\section{Practical training in the pre-certification cycle of doctors on the specialty «General practice-family medicine" on the topic of neurological examination of the patient (study of reflexes and sensitivity)}

\section{Svyrydova N.}

Department of Neurology and Reflexology, Shupyk National Medical Academy of Postgraduate Education

\section{Dovgiy I.}

Department of Neurology and Reflexology, Shupyk National Medical Academy of Postgraduate Education

\section{Sereda V.}

Department of Neurology and Reflexology, Shupyk National Medical Academy of Postgraduate Education

\section{Cherednichenko T.}

Department of Neurology and Reflexology, Shupyk National Medical Academy of Postgraduate Education

\section{Zhhilova N.}

Department of Neurology and Reflexology, Shupyk National Medical Academy of Postgraduate Education

\section{Resume}

The comprehensive approach of a family doctor to a patient can often be the basis for conclusions that are significantly different from those obtained in a one-sided, highly specialized medical approach. The structural and functional reorganization of the system of medical care with the primary development of primary health care on the basis of the general practice of family medicine, it is necessary to increase the level of qualification of primary care physicians from the territorial-district principle to the free choice of general medical (general) patients, taking into account the medical route the patient. Postgraduate qualification upgrades include a large percentage of practical training in the pre-certification cycle of doctors in the specialty "General Practice-Family Medicine» on the topic of neurological examination of the patient (reflexes and sensitivity studies). The neurological examination consists of two independent components: the collection of anamnesis of the disease and an objective study of the neurological status of the patient. The neurological status is a specific survey, and most neurological disorders only concern nervous system disorders, but some of them may be the result of general-somatic disorders, and therefore, at least a brief examination of the functions of the cardiac, respiratory, digestive and excretory systems, as well as a general review, should be performed.

Key words: neurological examination, family doctor, comorbidity, practical skills, practical classes, postgraduate education 